\title{
KACHLE Z HRADU GUTŠTEJNA
}

\section{LUBOŠ HOBL}

\begin{abstract}
Abstrakt: Př́spěvek se věnuje kamnářské keramice pocházející z archeologického výzkumu, který probíhal na hradě Gutštejn v letech 1997-2001. Během vyhodnocováni artefaktů bylo možné identifikovat nejméně čtyři chronologické fáze (od poloviny 15. do 2. poloviny 16. století), které se odlišovaly jak použitým materiálem a variabilitou morfologických částí, tak zejména reliéfnimi motivy na komorových kachlich. Některé varianty motivio jsou unikátní a nemaji žádné známé analogie. Jiné motivy naopak zcela odpovidají nálezům z jiných lokalit. I přes značnou fragmentárnost rozšiřuji prezentované soubory pramennou základnu a hlavně konkretizují naše povědomí o vybavení obytných prostor na tomto hradě.
\end{abstract}

Klíčová slova: Hrad Gutštejn - kamnové kachle - reliéfní motivy - Jan Žižka.

\section{Tiles from Gutštejn Castle}

Abstract: This article discusses stove ceramics yielded by archaeological research conducted at Gutštejn Castle in 1997-2001. In the course of the assessment of artefacts it was possible to identify at least four chronological phases (from the mid-15th century until the second half of the 16th century) that differed through the used materials and the variability of morphological parts, as well as, in particular, through the relief motifs on chamber tiles. Some motif variants are unique and have no known analogies, while others correspond with finds from other sites. Despite their fragmentary nature, the presented series expand the source base and help specify information about the equipment of the castle's residential quarters.

Key words: Gutštejn Castle - stove tiles - relief motifs - Jan Žižka.

\section{Úvod}

V průběhu roku 2013 a na počátku roku 2014 proběhla analýza keramických artefaktů z hradu Gutštejn (okr. Tachov). Tento materiál byl získán během několika sezon archeologických výzkumů v letech 1997-2000 (vlastně 2001) pod vedením Mgr. Evy Kamenické. Rozbor byl cílen na vytvoření chronologického modelu kuchyňské a stolní keramiky, a proto mu podléhaly pouze některé sondy, které měly pro tento účel potenciál. ${ }^{1} \mathrm{~V}$ nich se nacházelo, kromě cílených druhů keramiky a dalšího dodatkového materiálu, i poměrně značné množství zlomků kachlů (700 ks z celkového počtu 3488 analyzovaných zlomků). ${ }^{2}$ Vzhledem k takovému množství bylo přistoupeno $\mathrm{k}$ jejich samostatné analýze. Na jejím základě byly identifikovány čtyři ohraničené soubory. Ty byly vyčleněny na základě rozdílných motivů čelních vyhřívacích stěn (dále jen ČVS), s nimi korespondujícího keramického materiálu (keramické třídy) a morfologických vlastností. Všechny vyčleněné soubory budou v následném textu podrobněji charakterizovány.

Bohužel analyzovaný materiál byl značně fragmentarizovaný, což vedlo k omezení jeho vypovídací hodnoty. Většina nálezů (zařazených do souborů 1-3) pocházela ze sondy II/97, situované v prostoru jižního parkánu (obr. 1). Vrstvy, v nichž byly obsaženy, měly charakter zásypu navršeného v poměrně krátkém období, a to pravděpodobně někdy během druhé tř̌etiny 16 . století (Hobl 2015, 134). Soubor 4 se nacházel v sondě VII/98, jež byla umístěna v prostoru budovy na dolním nádvoří (Kamenická 1998, 5). V ostatních analyzovaných sondách se nacházelo pouze malé množství kachlových zlomků.

Pro potřeby tohoto příspěvku byl analyzovaný materiál doplněn i o některé další identifikovatelné reliéfní motivy z ostatních sond, aby se co nejvíce zvýšila vypovídací hodnota vymezených souborů ze sledované lokality.

1 Chronologický model a některá další z něho vyplývající zjištění byly publikovány na jiných místech (Hobl 2015; 2015a)

2 Všechny nálezy z výzkumu jsou uloženy v depozitárii archeologického oddělení NPÚ ÚOP v Plzni. 


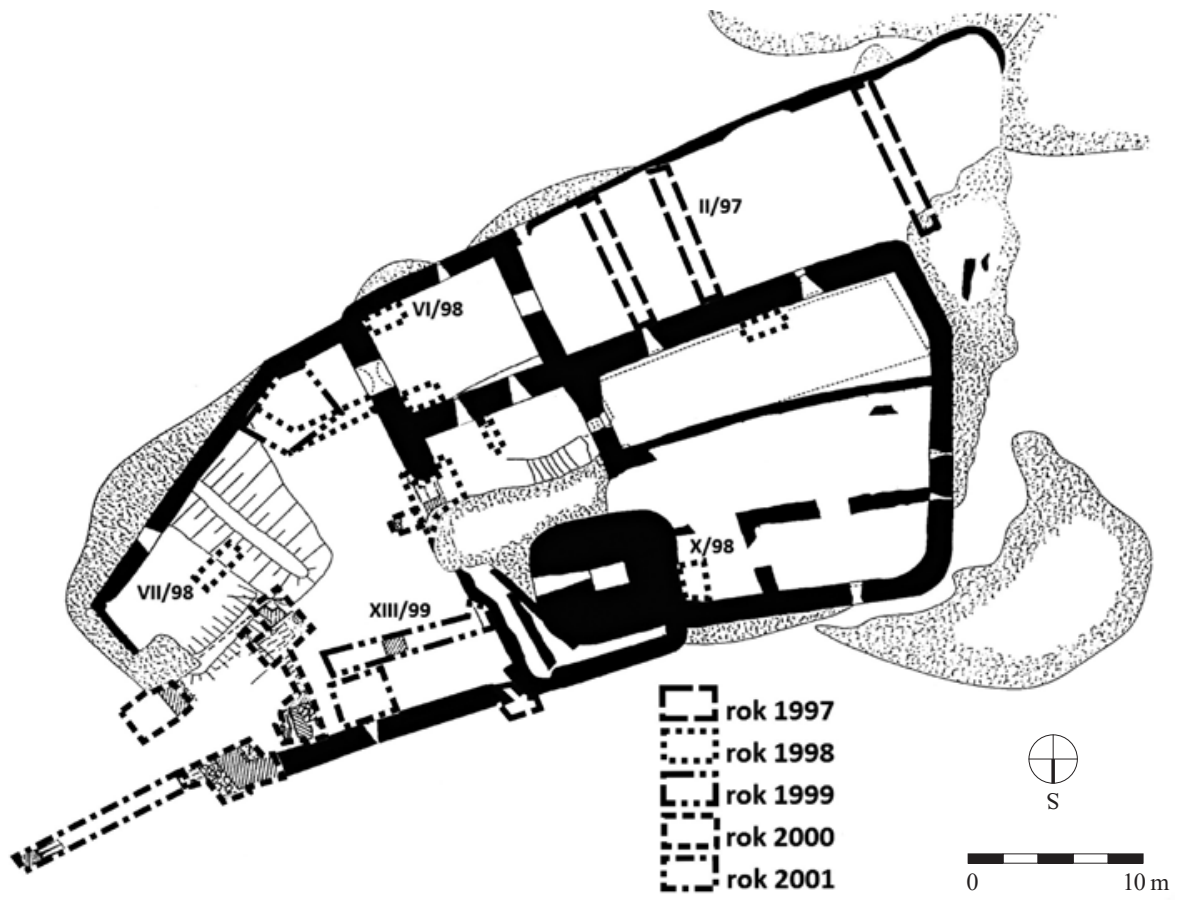

Obr. 1. Půdorys hradu s vyznačenými sondami - označené podléhaly analýze.

Abb. 1. Grundriss der Burg mit gekennzeichneten Sondiergrabungen - die nummerierten unterlagen einer Analyse.

\section{Soubor 1}

První vyčleněný soubor obsahoval jak komorové, tak i nádobkové kachle. Materiál, se kterým je skupina spojena, byl hrubozrnný, oxidačně pálený a snadno odlišitelný od hrnčiny běžné keramiky (keramická tř́́da GU4008). ${ }^{3}$

Komorové kachle měly vždy ČVS pokrytou zelenou olovnatou glazurou. Okrajová lišta ČVS byla provedena jako jednoduchý hranol. Vlastní komory kachlů byly poloválcové, vytáčené, jak ukazují zachované technologické stopy, na hrnčířském kruhu a posléze rozříznuté na polovinu. Průměr podstavy válce byl zhruba 22,5 cm (obr. 2). Výška komory bohužel není známa, ale pravděpodobně šlo o čtvercový formát; ovšem ani obdélný formát ČVS nelze zcela vyloučit. Vnitřek komory nese stopy po očazení a opálení. Zadní vyhřívací otvory byly bud' oválné, nebo kruhové. Vznikly vyříznutím do pláště, a proto jsou zakončeny téměř vodorovnou, případně lehce zaoblenou profilací. Pouze $\mathrm{v}$ jediném př́ípadně byl na fragmentu pláště komory zaznamenán kruhový záchytný otvor. Zajímavou skutečností je značně nekvalitní napojení ČVS a pláště komory. I přes tloušt'ku pláště kolem $1,5 \mathrm{~cm}$ spočívalo pouze na $4-5$ milimetrech (obr. 3). Ačkoliv se toto napojení ani v jednom př́ípadě nedochovalo, jeho identifikace byla možná na základě pozorování příslušných částí plášt’ů a negativů patrných na vnitřních stranách ČVS. Způsob takového provedení odpovídá výrobě nikových (výklenkových) kachlů, u nichž bylo připojení prováděno pouze z vnějšku (srov. Pařík-Hazlbauer 1991, 298). ${ }^{4}$

Na ČVS bylo možné identifikovat tři motivy. Z nich nejvýznamnějším byl motiv s Janem Žižkou v čele vojska. Č́sti ČVS s tímto motivem byly nalezeny v několika sondách. Ústřední postavou je vojevůdce Jan Žižka zobrazený jako vousatý muž s delšími vlasy, s páskou přes obě oči a čepicí na

3 Seznam a popis keramických tříd zde není, vzhledem k rozsahu, uveden. Dostupný je v rámci autorovy diplomové práce na straně https://portal.zcu.cz/portal/studium/prohlizeni.html pod záložkou kvalifikační práce.

4 Spojení na vnitřní straně tohoto typu kachlů nebylo možné, navíc prořezávaná čelní stěna plnila pouze dekorativní funkci. 
hlavě, jedoucí na koni a zároveň třímající v levé ruce palcát (obr. 4). Zobrazen je téměř v pohledu en face, zatímco jeho kủn̆ je z profilu. Za hejtmanem je skupina bojovníků (v totožném postavení jako jejich vůdce) ve zbroji se železnými klobouky, které doplňují kapuce (některé z nich jsou stylizované jako kroužkové), ozbrojených cepy. Nad hejtmanem se nachází druhý jezdec, který zřejmě drží praporec (ten se bohužel na žádném exempláŕi nezachoval, ale jeho př́tomnost evokuje jeho odlišná tloušt'ka dřevce oproti cepům bojovníků a shodnost s ikonografickými prameny, na nichž se zobrazuje vždy praporec s kalichem, viz níže). Dosavadní bádání o kachlových motivech nezaznamenalo na kachlích př́tomnost Jana Žižky s páskou přes obě oči a tak realistické zpracování obdobných motivů tohoto typu (srov. Pavlík-Vitanovský 2004, 97-98, obr. 574-578 na s. 243-244; Hazlbauer 1998, 205-207).

Velmi nápadná je podoba tohoto motivu s některými ikonografickými prameny, např́klad s iluminací v Göttingenském kodexu, jenž vznikl krátce po roce 1460 a z obdobných pramenů je nejstarší známý (obr. 5). Zde je rozložení námětu a i zobrazení postav (téměř en face) a koně (z profilu), respektive koní, velmi podobné, nicméně je možné pozorovat i rozdíly v detailech (nejvýraznější je absence kněze s monstrancí). Oproti výše zmíněnému Göttingenskému kodexu a i mladším iluminacím (např. známějšímu Jenskému kodexu) je motiv zrcadlově převrácený. To je s největší pravděpodobností způsobeno tím, že některá z obdobných ikonografií sloužila jako vzor při tvorbě matrice (tj. negativu). Proto také na motivu má Jan Žižka palcát v levé ruce, a nikoliv v pravé jako na všech výše zmíněných předlohách.
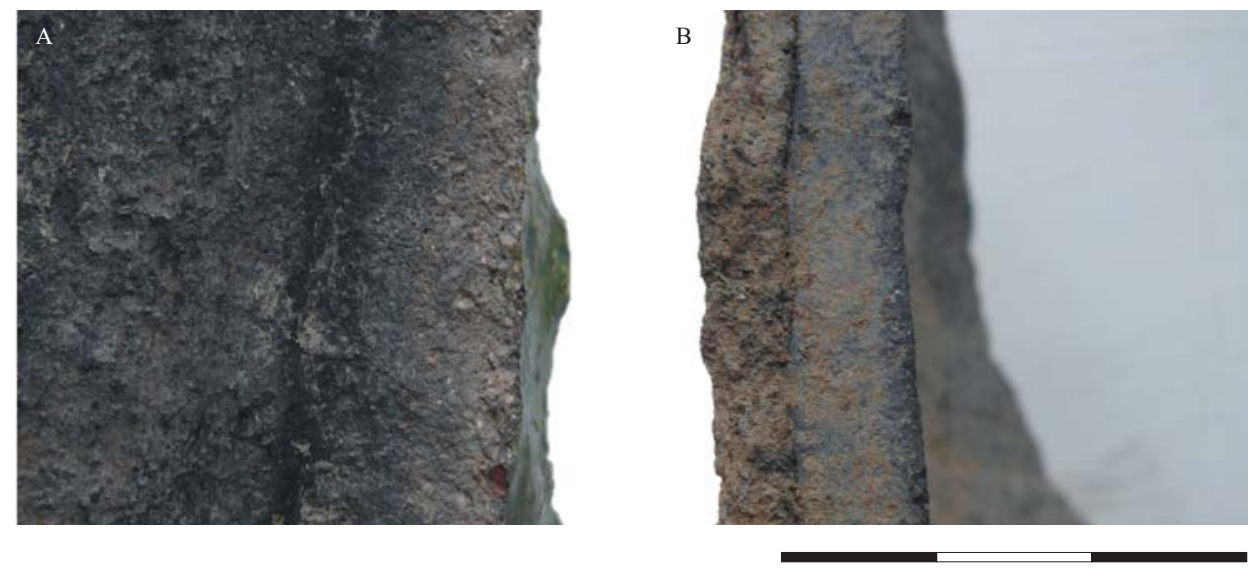

Obr. 3. Detailní pohled na zadní stranu ukazující malou plochu spojení těchto částí, charakteristickou pro všechny zlomky těchto částí v souboru 1 . A - čelní vyhřívací stěna, B - plášt'.

Abb. 3. Detailansicht auf die Rückseite mit kleiner Verbindungsfläche, wie sie für alle Fragmente dieser Teile in Komplex 1 charakteristisch sind. A - Blatt, B - Mantel. 

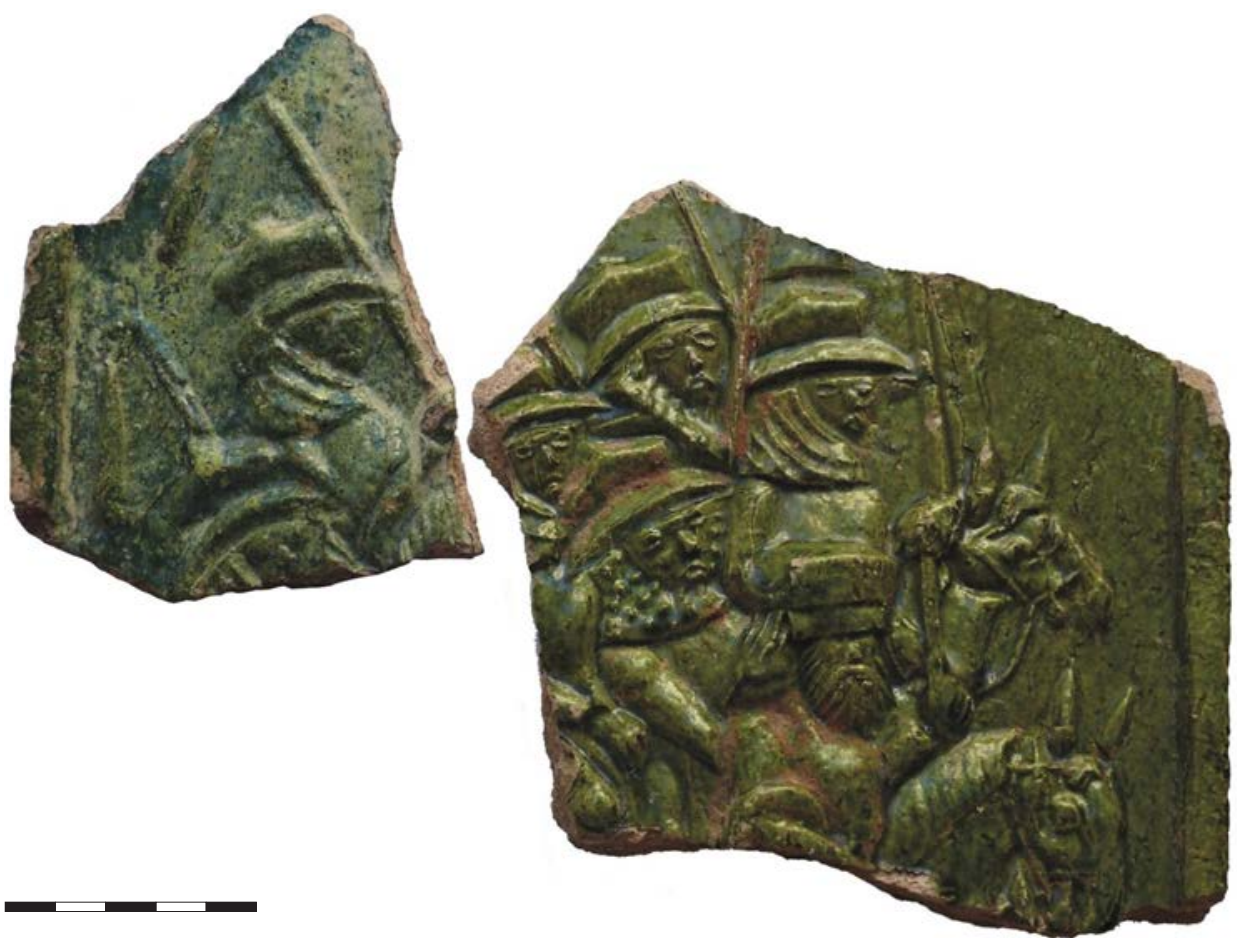

Obr. 4. Motiv s Janem Žižkou v čele vojska.

Abb. 4. Motiv mit Jan Žižka als Heerführer.

Dalším určeným byl motiv zemské aliance (orlice se lvem). V souboru byly dvě shodné ČVS s tímto heraldickým motivem (obr. 6). Na motivu je v dochovaných př́ípadech pouze orlice. Té z křídel a krku vystupují šlahouny, které zvyšují dekorativnost motivu. Ocas orlice se ve spodní části horizontálně rozšiřuje. Že jde o alianční motiv, je zřejmé z přítomnosti lvích drápů napravo od orlice, ale bližší podobu lva neznáme. Teoreticky by mohlo jít i o motiv např. panovnického znaku s těmito heraldickými zvířaty. ${ }^{5}$ Ovšem v takovém prŕípadně by kachle musely mít jiný než čtvercový formát ČVS, jelikož další části znaku by se při výšce orlice $13 \mathrm{~cm}$ (a to nikoliv kompletně dochované) na motiv již nevešly. Motiv aliančního spojení jen orlice a lva na ČVS je známý např. z Brna, i když provedení této varianty je odlišné (Vitanovský 2008, obr. 289 na s. 100).

Posledním rozpoznaným je motiv gotické kružby (slepé), lépe řečeno architektonického vzoru (obr. 7). Ten je identifikovatelný pouze na jediném zlomku na základě jednoho z laloků kružby a dalších doplňujících linií. Bližší popis není možný.

Nádobkové kachle měly pravoúhlé ústí, v souboru jsou zastoupeny dvěma odlišnými druhy okrajů (obr. 8:A, B). Jejich zařazení k tomuto souboru má své opodstatnění v použitém materiálu, totožném s materiálem komorových kachlů. Na pláštích se přitom nahodile vyskytovaly kapky stejné zelené glazury jako na ČVS komorových kachlů.

Datace souboru je možná hlavně na základě motivů. Stylizace orlice na aliančním motivu odpovídá obecně druhé polovině 15 . století. Avšak velká většina motivů s husitskou tematikou je datována do období okolo poloviny 15. století. Analogické ikonografické prameny (Göttingenský kodex) a umělecké provedení motivu s Janem Žižkou ukazuje spíš na o něco mladší dataci.

5 Motiv panovnického znaku, na kterém se orlice nachází v levém horním rohu vedle lva, je znám na kachlích z hradu Špilberka (Zikmund I.) a z hradu Cimburka (Albrecht V. Rakouský nebo Ladislav Pohrobek; Vitanovský 2008, obr. 296 a 297 na s. 101). 


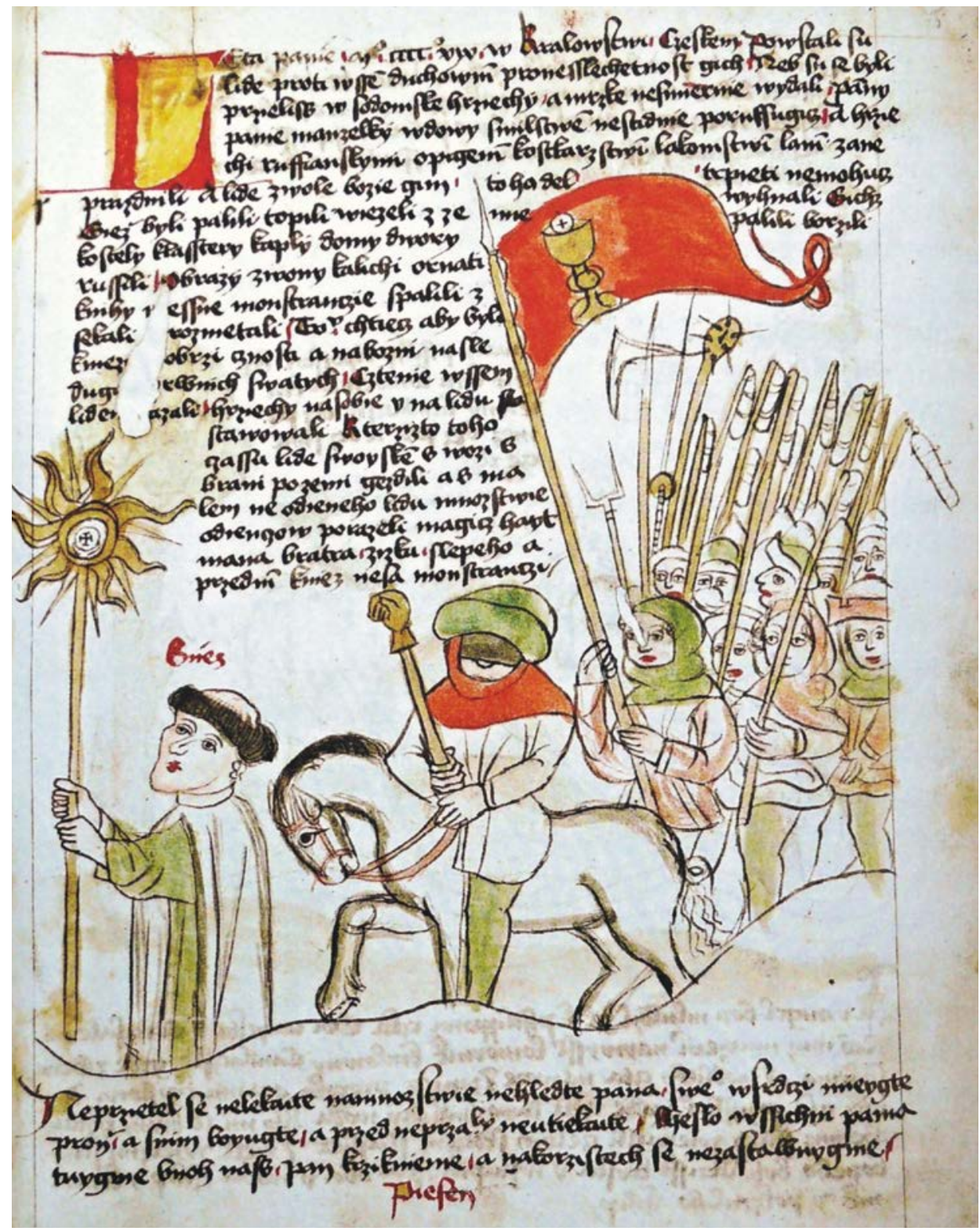

Obr. 5. Vyobrazení Jana Žižky v čele vojska v Göttingenském kodexu. Niedersächsische Staats- und Universitätsbibliothek Göttingen, 2 cod. Ms. Theol. 182 Cim, fol. 38r.

Abb. 5. Darstellung von Jan Žižka als Heerführer im Göttinger Kodex. Niedersächsische Staats- und Universitätsbibliothek Göttingen, 2 cod. Ms. Theol. $182 \mathrm{Cim}$, fol. 38r.

Proto zřejmě můžeme zařadit výše popisovaný soubor obecně do druhé poloviny 15 . století (ale pravděpodobněji do 3. čtvrtiny tohoto století). Velmi zajímavá je v tomto souboru př́ítomnost zelené glazury, která podtrhuje honosnost ztvárnění motivů a je v tomto období relativně vzácným jevem - nepochybně ještě zvýšila asi i tak vysokou pořizovací cenu (srov. Pavlík-Vitanovský 2004, 15; Hazlbauer 1998, 37-38). Je až zarážející, jak oba tyto prvky jsou v naprostém protikladu k nekvalitnímu napojení ČVS k vlastní komoře kachle. 


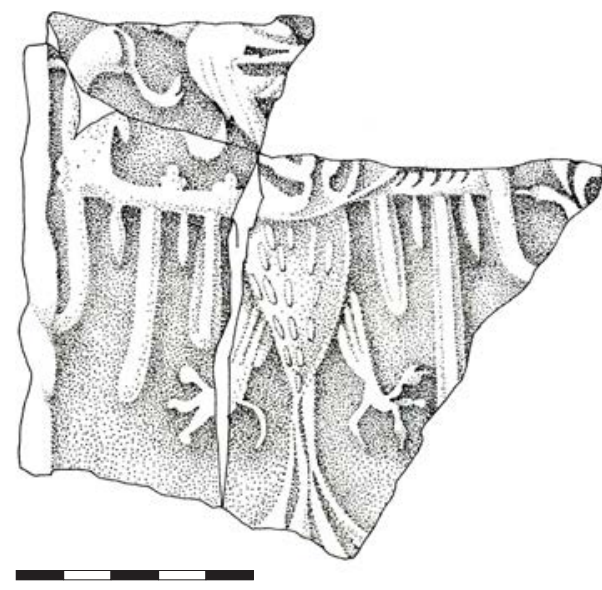

Obr. 6. Motiv zemské aliance. Kresba M. Šmejdová. Abb. 6. Motiv der Landesallianz. Zeichnung M. Šmejdová.

\section{Soubor 2}

I ve druhém souboru byly zastoupeny jak komorové, tak i nádobkové kachle. Oxidačně pálený materiál se od běžné keramiky výrazně neodlišoval, ale byl jednoduše vydělitelný (hlavně keramická třída GU4006, kterou bylo možné spojit pouze s kamnářskou keramikou).

Komorové kachle měly vždy režné ČVS. Žádná z kachlových komor se nezachovala, nicméně pravděpodobně šlo o nejběžnější typ tzv. kuželovité komory. Její rozměry bylo možné určit pouze částečně. Vodítko pro určení velikosti její přední části je jediný měřitelný exemplář ČVS základního řádkového kachle $(18,5 \times 20,5 \mathrm{~cm})$. Zadní vyhřívací otvory komor byly kruhové, o průměru okolo $13 \mathrm{~cm}$, $\mathrm{s}$ větším množstvím přehnutých a oble podseknutých profilací (obr. 9). Na části fragmentů plášt’ů byly přítomny zbytky pojicích výmazů. Současně na několika málo zlomcích byly kruhové, př́ípadně oválné záchytné otvory. Napojení ČVS k plášti komory bylo oproti předchozímu období kvalitní - plášt' se v místě spojení jednostranně nožičkovitě rozšiřoval a přiléhal k ČVS tak, aby styková plocha co největší.

Na běžných komorových kachlích se vyskytovaly motivy starozákonnich postav (proroků) s nápisovou páskou. První př́iklad představuje mírně natočená mužská polopostava (s rozměry ČVS 18,5 × 20,5 cm; obr. 10). Ve spodní části se vyskytuje skládaná nápisová páska, kterou postava přidržuje levou rukou. Páska obsahuje slovo IONA(S), takže by postava měla zobrazovat proroka Jonáše. Prstem pravé ruky ukazuje do míst, kde se na některých analogických motivech nachází hvězda. Prorok je oblečen do kabátce s nabíranými rukávy, ale oproti obdobným variantám nejsou patrné zapínací knoflíky. Na jejich místech je pouze pět drobných prohlubní. Bohužel nevíme, co měla postava na hlavě (tato část chybí). U tohoto motivu to často bývá královská ko- 
runa. Její přítomnost (spolu s výše zmíněnou hvězdou v rohu) vede $\mathrm{k}$ tomu, že část badatelů označuje tento motiv jako krále Davida a nápis odkazující na Jonáše považují za chybný (Pavlík-Vitanovský 2004, 35). Shodná korunová varianta je známa z Tábora (Krajíc 2005, obr. 35 na s. 30). Další varianta motivu, ale bez koruny na hlavě, pochází např. z Horšovského Týna (Dudková-Orna 2007, 34, obr. 5:4 na s. 35). Druhou postavu proroka nelze jednoznačně určit, mohlo by však jít o proroka Daniela (srov. Hazlbauer 1998, obr. 35 na s. 74 nebo Brych 2004, obr. 95 na s. 64). Na zlomcích je patrná pouze hlava se svisle proplétaným turbanem a část nápisové lišty (obr. 13:A).

Dalším byl motiv s jelenem. Tento motiv se objevuje na několika fragmentech. Nejlépe je zachována přední část těla jelena, který je evidentně v pohybu (obr. 13:B). Vzhledem k velikosti jelena je zřejmé, že nebyl jediným elementem motivu. Otázkou zůstává, kam ho žánrově zařadit; nabízí se, že šlo bud' o alegorický, nebo profánní motiv (např. loveckou scénu; blíže k motivům s jelenem viz PavlíkVitanovský 2004, 72-73, 101).

$\mathrm{V}$ tomto souboru rovněž zaznamenáváme několik druhů ukončovacích prvků kamen. Jako první můžeme jmenovat řimsový kachel. Ten měl v horní části cimbuří tvořené dvěma zuby (částečně upravené jako pultové stř́šky), mezi nimiž je proluka, přitom poloviny těchto proluk jsou ještě na vnějších stranách zubů. Jeho rozměry byly $18 \times 14,5 \mathrm{~cm}$, výška v místě zubů cimbuří $18,5 \mathrm{~cm}$. Na ČVS se nacházel motiv dvou ornamentálních rozet. Obě rozety byly v koncentrických rámcích doplněných trojlístky (obr. 11). Naprosto stejné motivy na římsových kachlích známe z hradu Točník a ze Zvíkovce na Rokycansku (Pavlík-Vitanovský 2004, 439, obr. 1306; Brych 2004, 128, obr. 286 na s. 128).

Dalším zastoupeným ukončovacím prvkem byl korunní nástavec (akroterium). Jeho plochu ohraničují dvě, respektive tři plastické linie, z nichž vnitřní se uzavírají do lomených oblouků. Linie se pak zvedají do zakončení, které mělo představovat fiálu nebo hrot. Ve středu se nacházel motiv bliže neurčených plo-

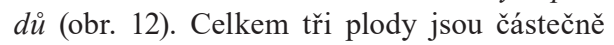
omlety. Pouze na jediném se zachovaly plastické tečky. Obvykle jsou obdobné motivy označovány jako hrozny nebo šištice. Mohlo by rovněž jít o stylizovaná granátová jablka (?).

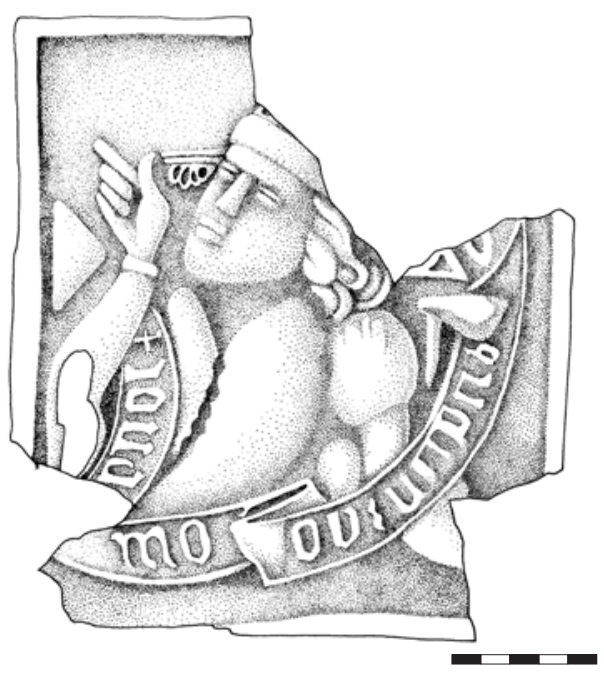

Obr. 10. Motiv proroka Jonáše. Kresba M. Šmejdová. Abb. 10. Motiv des Propheten Jonas. Zeichnung M. Šmejdová.

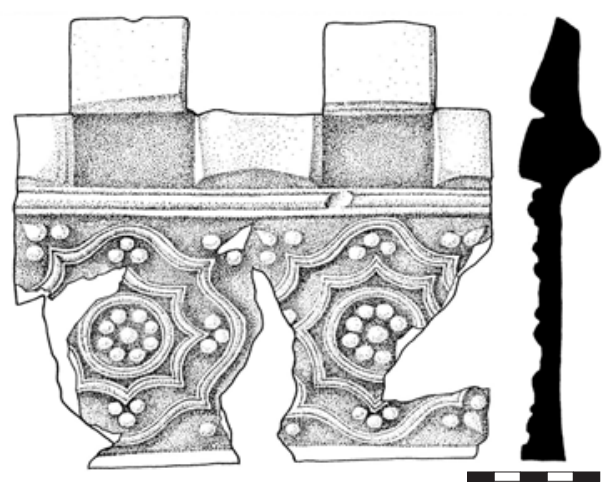

Obr. 11. Římsový kachel s motivem ornamentálních rozet. Kresba M. Šmejdová.

Abb. 11. Simskachel mit ornamentalem Rosettenmotiv. Zeichnung M. Šmejdová.
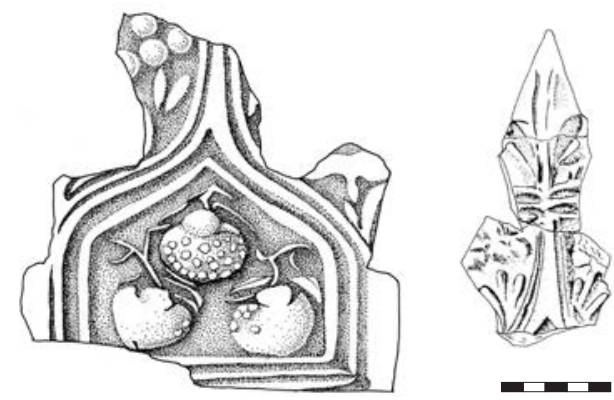

Obr. 12. Korunní nástavec s motivem blíže neurčených plodů. Kresby M. Šmejdová a E. Ventrubová.

Abb. 12. Bekrönungsaufsatz mit Motiv von nicht näher bestimmten Früchten. Zeichnungen M. Šmejdová und E. Ventrubová. 
Posledním ukončovacím článkem mohla být volná lišta. Pozůstatkem po ní by mohly být dva trojlístky, které jako jediné v tomto souboru pokrývala olovnatá žlutozelená, částečně transparentní glazura (obr. 13:C).

Velké množství zlomků náleželo nádobkovým kachlưm s pravoúhlým ústím. I zde bylo možné přiřazení pouze na základě specifického materiálu. Na vnější straně jejich plášt’ů je dobře patrná záchytná šroubovice. I u tohoto typu kachlů byla větší variabilita okrajových profilací (obr. 8:C-H).

Zaznamenány byly i tři zlomky oxidačně pálených prořezávaných stěn, avšak není možné určit, z které části kamen pocházejí (obr. 13:D-F).

Datace všech přítomných motivů je možná na přelom 15. a 16. století. Oproti předchozímu souboru na kachlích nebyla zaznamenána glazura (s výjimkou výše popsaných trojlístků). Velmi zajímavá je výše popsaná př́ítomnost hned několika druhů horního ukončení kamen.
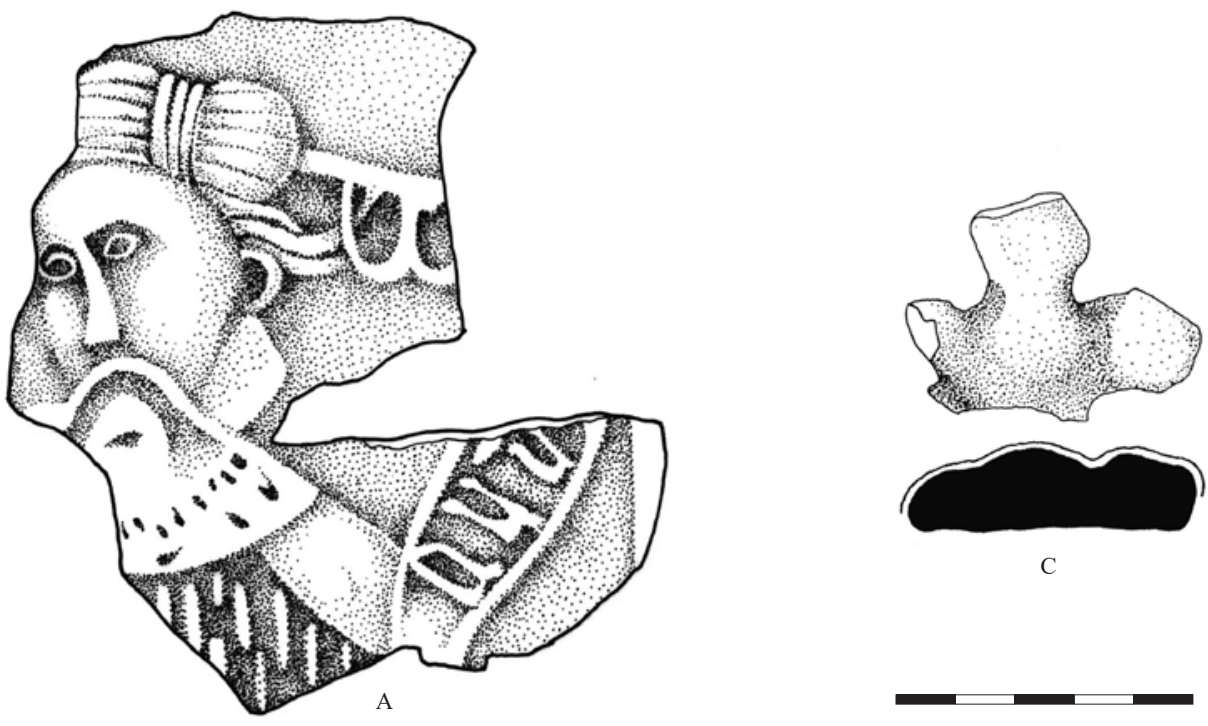

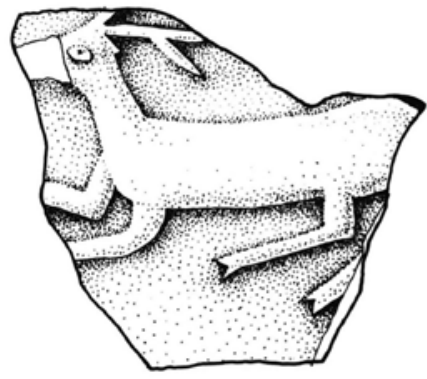

B

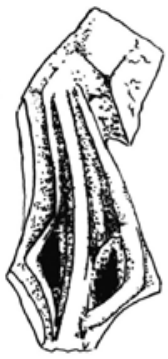

D

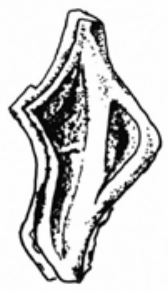

E

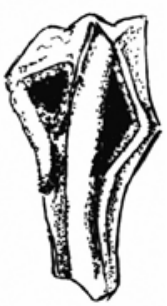

F

Obr. 13. Doplnění souboru 2. A - motiv blíže neurčeného proroka s nápisovou páskou, B - motiv s jelenem, C - trojlístek s glazurou, možná součást volné ukončovací lišty, D-F - články prořezávaných stěn. Kresby M. Šmejdová a E. Ventrubová. Abb. 13. Ergänzungen zu Komplex 2. A - Motiv eines nicht näher bestimmten Propheten mit Inschriftbanderole, B Hirschmotiv, C - Kleeblatt mit Glasur, möglicherweise Bestandteil einer freien Abschlussleiste, D-F - Elemente durchbrochener Wandungen. Zeichnungen M. Šmejdová und E. Ventrubová. 


\section{Soubor 3}

Třetí soubor tvořily pouze komorové kachle. Materiál, jímž jsou tvořeny komory, je totožný s materiálem v předchozí skupině (GU4006). Rozdílný je však materiál ČVS. Ten je bělavý bez makroskopicky pozorovatelných příměsí.

Výše zmíněné ČVS komorových kachlů vždy pokrývá světle či tmavě zelená olovnatá glazura. Samotné komory byly pravděpodobně kuželovité. Jejich fragmenty není možné, z výše zmíněných důvodů, odlišit od předchozí skupiny. Jediným vodítkem pro jejich zařazení do tohoto souboru mohou být ojedinělé kapky zelené glazury na zlomcích pláště. Spojení mezi komorou a ČVS bylo obdobně kvalitní jako v předchozím souboru.

$\mathrm{Na}$ ČVS se vyskytovaly pouze rostlinné motivy. Ty byly z větší části fragmentární a neumožňují bližší popis. Na těchto relativně malých zlomcích nacházíme např. listy nebo kvítky (obr. 14:B, C). Jediný charakterizovatelný motiv tvoří rozeta ve tvaru květu. Na ní jsou rozeznatelné dvě řady okvětních lístků (obr. 14:A).

Soubor je možné zařadit do průběhu první poloviny 16. století. Tomu odpovídají jednak rostlinné motivy a jednak přítomnost glazury. Oba tyto znaky jsou typické pro přechod k renesanci (Pavlík-Vitanovský 2004, 174).
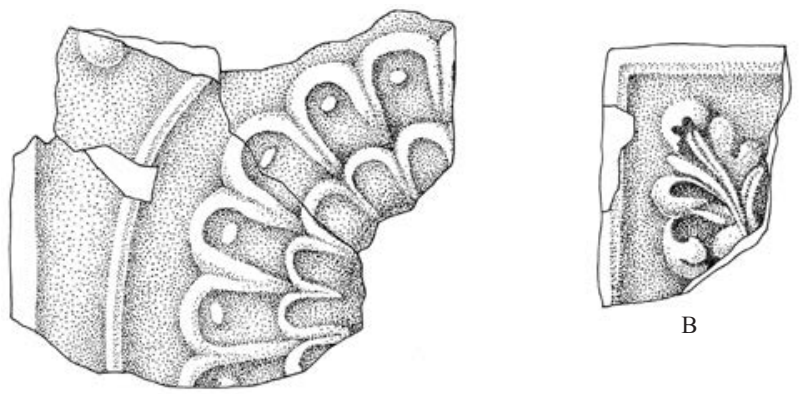

$\mathrm{B}$

A

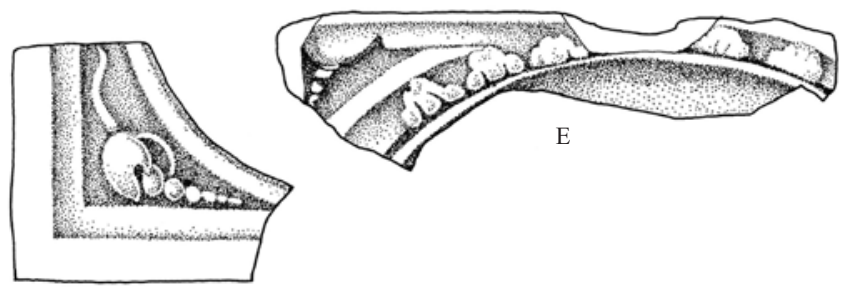

$\mathrm{D}$

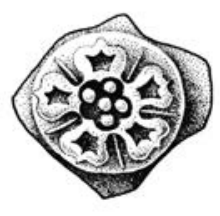

C
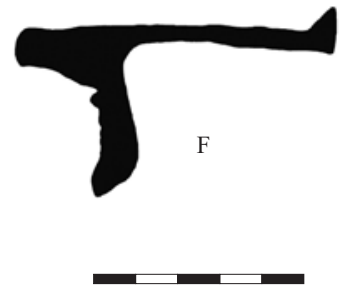

Obr. 14. Výběr motivů v souboru 3; motiv a profil rámového kachle v souboru 4. A-C - rostlinné motivy, D, E - miskovitá zahloubení s rostlinným dekorem. Kresby M. Šmejdová a L. Hobl.

Abb. 14. Motivauswahl von Komplex 3; Motiv und Profil einer Rahmenkachel in Komplex 4. A-C - Pflanzenmotive, D, E napfartige Vertiefung mit Pflanzendekor. Zeichnungen M. Šmejdová und L. Hobl.

\section{Soubor 4}

Poslední soubor tvoří opět pouze komorové kachle. Jejich materiál je poměrně jemný a na povrchu hlazený až zaleštovaný beze stop po glazuře (GU4025).

Komorové kachle obíhala po obvodu ČVS kuželovitá okrajová lišta, která předstupuje před plochu ČVS o $2 \mathrm{~cm}$. Spoj mezi ČVS a pláštěm není patrný a zdá se, že kachle byly vytvořeny jako jeden celek. Samotná komora byla přetvořena do rámu o šířce ca $5 \mathrm{~cm}$ po celé délce (obr. 14:F). Zadní vyhřívací otvor tohoto rámu byl čtvercového půdorysu se zaoblenými rohy. Profil okraje byl rozšířený na vnějši stranu komory a vodorovně seř́iznutý. 
ČVS tvořila miskovitá zahloubení s rostlinným dekorem. Středové zahloubení bylo na vnější straně svého obvodu zdobené drobnými lístky, které byly v rozích doplněny drobnými kvítky (obr. 14:D, E).

Použitý motiv se běžně vyskytuje v druhé polovině 16 . století. Oporou k této dataci je i zkracující komora do rámu - typická pro pokročilé renesanční období (Brych 2004, 5).

\section{Zařazení souborů do kontextu vývoje hradu a jeho držitelů}

Výše nastíněné datace souborů pochopitelně vyvolají otázku, kdo mohli být objednavatelé těchto několika kamen. ${ }^{6}$ Ovšem nelze na ni jednoduše odpovědět. Po polovině 15 . století jsou majetkové poměry hradu komplikované, nacházel se zřejmě nějaký čas i v držení vedlejších větví zakladatelského rodu pánů z Gutštejna. Hlavní větvi se vrátil až někdy v 60 . letech, jmenovitě do rukou Buriana II. z Gutštejna (Úlovec-Jánský 2000, 83). Ten patřil k nejbohatším šlechticům své doby. ${ }^{7}$ Pravděpodobně by právě on mohl být objednavatelem honosných kamen spojitelných se souborem 1, i když Gutštejn nebyl jeho sídelním hradem. Nicméně v takovém případě se př́tomnost husitského motivu s Janem Žižkou může jevit nezvykle, jelikož Burian II. byl, stejně jako jeho otec (člen plzeňského landfrýdu), katolíkem, zakladatelem karmelitánských klášterů (což v této době již nebylo úplně obvyklé) a do roku 1470 členem Zelenohorské jednoty (Úlovec-Jánský 2000, 83-84; Jánský 2009, 108-184). Bohužel nálezové okolnosti, pravděpodobná absence dalších motivů a jejich neznámé rozložení na tělese kamen neumožňují smysluplné vysvětlení tohoto jevu.

Datace souborů 2 a 3 naznačují, že kamna jim odpovídající vznikla v období nedlouho po sobě, tj. na přelomu 15. a 16. století a v první polovině 16 . století. V této době již vlastnili hrad v nedílu synové Buriana II. - Kryštof, Jindřich, Jetřich, Jan a Wolf. Žádný však na hradě nesídlil a využíván byl i druhou (všerubskou) větví rodu. V roce 1503 ho Jiřík Všerubský z Gutštejna využíval při své soukromé válce s knížetem Jiřím Saským (Úlovec-Jánský 2000, 85). Takové aktivity charakterizují prakticky celou první třetinu 16. století. Bratři z Gutštejna měli spory s králem i s okolními městy a podporovali zemské škůdce, jako byl např. Jan Bavůrek ze Švamberka. Po jeho popravě se na nějaký čas situace zklidnila (Úlovec-Jánský 2000, 87-88). V srpnu 1507 se na Gutštejně konalo jednání, které vedl, jako pověřenec nejvyššího kancléře, Jetřich z Gutštejna, s diplomaty kurfiřta Filipa Falckého. Z toho vyplývá, že hrad musel být ve stavu, který dovoloval hostit vyslance jednoho z významných ř́šských knížat (Úlovec-Jánský 2000, 88). Některé z interiérů $\mathrm{v}$ této době patrně byly vybaveny kachlovými kamny, jejichž pozůstatky byly zařazeny do výše jmenovaných souborů.

V následujících letech se opovědníci a zemští škůdci na hrad vrátili a nedá se předpokládat výraznější rozvoj obytné složky. V letech 1509-1510 byla postupně bratrům z Gutštejna, za jejich přečiny proti zemskému míru, odebrána značná část jejich majetků a klesali i na společenském žebřričku. Postupně se zadlužovali a rodový hrad se kolem roku 1520 dostal do držení jejich věřitele Mořice Širntyngára ze Širntyngu. I za něho se na Gutštejně vyskytovaly různé skupiny jako v předchozích obdobích (Úlovec-Jánský 2000, 91). V roce 1534 se hrad navrátil do rukou zakladatelského rodu. Nálezový kontext, v němž se nacházela dominantní část analyzovaných fragmentů ze souborů $1-3$, byl pravděpodobně navršen v rámci sanace úprav hradních prostor po výše popsaných obdobích (Hobl 2015, 134).

Další otázkou je umístění kamen. Vývoj hradu byl extrémně složitý. ${ }^{8} \mathrm{~V}$ polovině 15 . století se v hradním jádře nacházely dva paláce. Sonda na parkánu, odkud pocházejí nálezy, je umístěna př́mo pod jižním palácem. Ten byl plochostropý a minimálně patrový (srov. Durdík-Úlovec 1996, 70-77). První patro tohoto paláce vzniklo, jak dokládá dendrochronologické datování,

6 Pro potřeby tohoto prríspěvku není potřeba se zabývat celou historií hradu, která byla již několikrát zpracována, například Augustem Sedláčkem (1905, 50-53), Georgem Schmidtem (1925, 34-54) a naposledy Jiřím Úlovcem a Jiřím Jánským (2000).

7 Vlastnil celkem jedenáct panství, na nichž bylo velké množství hradů a měst, přes 500 vesnic a 1700 mlýnů, a také měl ve správě některá česká léna v dnešním Německu (Úlovec-Jánský 2000, 83; Jánský 2009, 108-184).

8 Stavebně historický průzkum byl zpracován T. Durdíkem (Durdík-Úlovec 1996; ve zkrácené a upravené verzi viz Durdík 2000, 143-146, nebo Durdík-Sušický 2005, 38-42). 
někdy po roce 1439 (Procházka 2004, 153). Obsahovalo nejméně tři místnosti, z nichž nejzápadnější měla roubenou výdřevu (Durdík-Úlovec 1996, 97-98). V takových místnostech byla často umístěna kachlová kamna, a právě proto i zde jejich přítomnost můžeme předpokládat. ${ }^{9}$ Severní palác, při hlavní věži, byl dvouprostorový, plochostropý a trojpatrový. Bohužel v jeho pozůstatcích nejsou viditelné žádné stopy po otopných zařízeních (srov. Durdík-Úlovec 1996, 81-85). Později v průběhu druhé poloviny 15. století bylo při jižním paláci ještě přistavěno dnes zcela zaniklé obytné patro parkánového kř́ídla zřejmě hrázděné nebo roubené konstrukce (Durdík-Úlovec 1996,66-68, 99). Bohužel celkový stav dochování obytných prostor hradu neumožňuje blíže určit umístění kachlových kamen.

Nálezy přiřazené $\mathrm{k}$ souboru 4 byly nalezeny v sondě v místě budovy na dolním nádvoří. Soubor je datován do druhé poloviny 16. století. Z toho vyplývá, že budova byla využívána i poté, co přestal být hrad centrem panství v roce 1549 . V tomto roce byl prodán a připojen k sousedním Bezdružicím. ${ }^{10}$ Obecně se předpokládá postupné chátrání hradu a jeho definitivní zánik za třicetileté války (Úlovec-Jánský 2000, 95-96).

\section{Závěr}

Analyzovaný materiál umožnil vyčlenit čtyři výše charakterizované soubory, které ukazují módní změny kachlových kamen zhruba od poloviny 15 . století do druhé poloviny 16 . století. Ty jsou reprezentovány hlavně změnou motivů ČVS, z nichž některé mají své analogie na jiných lokalitách, ale jiné, at' už motivy nebo jejich varianty (zejména pak motiv s Janem Žižkou), byly zcela neznámé a svým zpracováním výjimečné. Nejenže tedy rozšiřují pramennou základnu, ale zvyšují rovněž naše povědomí o vybavenosti místností na tomto hradě.

Fragmentárnost souborů a jejich nálezový kontext ovšem neumožňuje blíže rekonstruovat celkovou podobu kamen. Např́íklad není jasné, zda byly nádobkové a komorové kachle, obsažené v souborech 1 a 2, nějak kombinovány, nebo jimi byla opatřena samostatná kamna (což se zdá pravděpodobnější). Nadto velká variabilita ukončovacích prvků v souboru 2 naznačuje i větší počet kamen vzniklých v kratším období.

Závěrem je možné poznamenat, že další analýza materiálu (hlavně z prostoru zasypané cisterny v jihozápadním rohu dolního nádvoří a zbylých sond v prostoru jižního parkánu) by sice mohla přinést další informace o tomto druhu keramických výrobků, ale tato zjištění by už neměla výrazně vybočovat ze zde nastíněných tendencí. Týkat by se měla hlavně konkretizování podoby komor kachlů a také nádobkových kachlů, jelikož větší část identifikovatelných reliéfních motivů je součástí již této práce. ${ }^{11}$

Tato studie je dílčím výsledkem projektu Studentské grantové soutěže Západočeské univerzity v Plzni SGS-2016-068 „Studium vybraných sídelních struktur dlouhého trvání v západních a jižních Čechách“.

\section{Prameny a literatura}

BRYCH, V., 2004: Kachle doby gotické, renesanční a raně barokní. Výběrový katalog Národního muzea v Praze. Praha.

DUDKOVÁ, V.-ORNA, J., 2007: Gotické a renesanční kachle z výzkumu horní části náměstí Republiky v Horšovském Týně v roce 2006. In: Sborník Západočeského muzea v Plzni, řada Historie XVIII, 30-52. Plzeň.

DURDÍK, T., 2000: Ilustrovaná encyklopedie českých hradů. Praha.

\footnotetext{
9 U této místnosti se navíc nachází zazděný otvor, který by mohl být pozůstatkem vlašského komínu. Jeho vztah k místnosti s výdřevou však není jasný (srov. Durdík-Úlovec 1996, 71-72, 98). Tato místnost s roubenou výdřevou byla později radikálně přestavěna. Roubení bylo odstraněno a na jižní straně vznikla dvě velká okna. Tyto úpravy jsou předpokládány do 1. poloviny 16. století (Durdík-Úlovec 1996, 99). I to by mohlo podporovat dataci vzniku nálezové situace na jižním parkánu (viz výše). 
DURDÍK, T.-SUŠICKÝ, V., 2005: Zříceniny hradů, tvrzí a zámků - Západní Čechy. Praha.

DURDÍK T.-ÚLOVEC, J., 1996: Hrad Gutštejn. Katastrální území Okrouhlé Hradiště, okr. Tachov. Stavebně historický průzkum, rkp. ulož. v NPÚ ÚOP v Plzni.

HAZLBAUER, Z., 1998: Krása středověkých kamen. Odraz náboženských idejí v českém uměleckém řemesle. Praha.

HOBL, L., 2015: Keramický soubor z hradu Gutštejna, Acta Fakulty filozofické Západočeské univerzity 7 , č. 2, 125-153. Plzeň.

- 2015a: Věž hradu Gutštejna z pohledu archeologie, CB 15, 130-139.

JANSKÝ, J., 2009: Hroznatovci a páni z Gutštejna. Domažlice.

KAMENICKÁ, E., 1998: Předběžná nálezová zpráva o předstihovém archeologickém výzkumu v roce 1998, rkp. ulož. v NPÚ ÚOP v Plzni.

KRAJÍC, R., 2005: Středověké kamnářství. Výzdobné motivy na gotických kachlích z Táborska. Tábor.

PAŘÍK, V.-HAZLBAUER, Z., 1991: Technologie výroby gotických kachlů s prořezávanou čelní stěnou Ein Kachelofen aus dem 15.-16. Jahrhundert zwei Beispiele für eine fachübergreifende Zusammenarbeit, AH 16, 293-304.

PAVLÍK, Č.-VITANOVSKÝ, M., 2004: Encyklopedie kachlů v Čechách, na Moravě a ve Slezsku. Praha.

PROCHÁZKA, Z., 2004: Nové letopočty v dějinách hradů Plzeňského kraje. Př́ispěvek k dendrochronologickému datování a stavebnímu rozboru zdiva hradních zřícenin. In: Dějiny staveb. Sborník příspěvků z konference Dějiny staveb 2003, 144-175. Plzeň.

SEDLÁČEK, A., 1905: Hrady, zámky a tvrze království Českého XIII. Plzeňsko a Loketsko. Praha.

SCHMIDT, G., 1925: Bürgen Westböhmens. I. Teil, Ein Handbüchlein für Wanderer, Heimat- und Geschichtsfreunde. Stř́íbro.

ÚLOVEC, J.-JÁNSKÝ, J., 2000: Hrad Gutštejn. In: Západočeský historický sborník 6, 75-103. Plzeň.

VITANOVSKÝ, M., 2008: Heraldické motivy. In: Krása, která hřeje. Výběrový katalog gotických a renesančních kachlů Moravy a Slezska (Menoušková, D.-Měřínský, Z., edd.), 90-115. Uherské Hradiště.

\section{Zusammenfassung}

\section{Kacheln von Burg Guttenstein}

Der vorliegende Beitrag beschäftigt sich mit Ofenkeramik von Burg Guttenstein (Bezirk Tachov), die von einer in den Jahren 1997-2001 durchgeführten archäologischen Grabung stammt. Die Analyse dieser Art von Artefakten erfolgte nicht primär, sondern wurde aufgrund ihrer Vorkommenshäufigkeit separat durchgeführt. Insgesamt konnten vier selbständige Komplexe, bzw. chronologische Phasen ausgegliedert werden. Diese wurden dann anhand der unterschiedlichen Motive des Blattes, der morphologischen Eigenschaften und des mit ihnen korrespondierenden Keramikmaterials (Keramikklassen) untergliedert. Der erste, aus Blattkacheln bestehende Komplex wurde in die zweite Hälfte des 15. Jahrhunderts datiert. Das wichtigste Reliefmotiv dieser Gruppe ist das Motiv von Jan Žižka als Heerführer, wozu gegenwärtig keine bekannte Analogie existiert, jedoch eine auffällige Ähnlichkeit zu den ikonographischen Quellen aus jener Zeit besteht (die älteste bekannt Quelle ist der nach 1460 entstandene Göttinger Kodex). Zu den charakteristischen Merkmalen dieses Komplexes zählt die (für jene Zeit ungewöhnliche) grüne Glasur auf der Oberfläche des Blattes und seine qualitativ niedrige Verbindung mit dem Kachelmantel. Der zweite Komplex kann der Wende des 15. und 16. Jahrhunderts zugeordnet werden. In dem Komplex befanden sich mehrere Abschlusselemente des Ofens (Simskacheln, Krönungskacheln und möglicherweise auch eine freie Dekorleiste). Der dritte, aus der ersten Hälfte des 16. Jahrhunderts stammende Komplex trägt Merkmale der aufkommenden Renaissance. Als solche kann man vegetative Motive und die Glasur des Blattes ansehen. Der vierte und letzte Komplex wies bereits Elemente auf, die für die zweite Hälfte des 16. Jahrhunderts, bzw. für die forgeschrittene Renaissance typisch sind. Dies betrifft besonders die kürzer werdenden Rümpfe bei Rahmenkacheln und napfartige Vertiefungen mit Pflanzendekor. Durch diese Komplexe wird der Quellenfundus auch trotz ihres geringen Aussagewerts erweitert. Gleichzeitig präsentieren sie die der Mode unterworfenen Veränderungen von Kachelöfen und dieser Burg. 
Die vorliegende Studie ist Teilergebnis des Studentischen Förderwettbewerbprojektes der Westböhmischen Universität in Pilsen SGS-2016-068 „Studium ausgewählter und nachhaltiger Siedlungsstrukturen in Westund Südböhmen“.

Mgr. Luboš Hobl, Katedra archeologie Filozofické fakulty Západočeské univerzity v Plzni, Sedláčkova 15, 30614 Plzeň, Česká republika, Hobl.L@seznam.cz 
